\title{
A new surgical technique to treat corneal perforations using amniotic membrane and surgical adhesive
}

\author{
[Nova técnica cirúrgica para tratamento de perfuração de córnea utilizando membrana \\ amniótica e adesivo cirúrgico] \\ K.C.S. Pontes ${ }^{1}$, A.P.B. Borges ${ }^{1}$, R.B. Eleotério ${ }^{1}$, A.C.N. Frazão ${ }^{1}$, D.P.D. Machado ${ }^{1}$, \\ E.C.C. Reis ${ }^{1}$, R.V. Sepúlveda ${ }^{1}$, T.S. Duarte ${ }^{1}$, J.L. Laus ${ }^{2}$ \\ ${ }^{1}$ Universidade Federal de Viçosa - Viçosa, MG \\ ${ }^{2}$ Faculdade de Ciências Agrárias e Veterinárias - UNESP-Jaboticabal - Jaboticabal, SP
}

\begin{abstract}
The objectives of this study were to compare surgical techniques and the effects of using n-butyl 2cyanoacrylate and bovine amniotic membrane to repair perforated lesions in corneas. Penetrating keratoplasty was performed in sixty New Zealand White rabbits under general anesthesia. Group 1 (G1) was treated with n-butyl 2-cyanoacrylate, group $2(\mathrm{G} 2)$ received a fragment of amniotic membrane through the anterior chamber and application of n-butyl 2-cyanoacrylate over the lesion, group 3 (G3) was treated with the same technique as G2 with the addition of an amniotic membrane bandage covering the cornea and sutured in the limbus region, and group 4 (G4) was treated with an amniotic membrane sutured to the lesion and an amniotic membrane bandage sutured in the limbus region. Clinical, histological and histomorphometric examinations of the corneas were performed. The membrane acted as a barrier for aqueous humor in G2 and G3, thereby keeping the surface dry for adhesive application; it also prevented the adhesive from contacting intraocular structures. The groups treated with amniotic membrane and surgical adhesive showed better results than the groups treated with either material alone. Thus, the combination of the membrane with the adhesive is recommended for this type of lesion.
\end{abstract}

Keywords: rabbits, cornea, cyanoacrylate, glycerin, ophthalmic surgery

\section{RESUMO}

Os objetivos deste estudo foram comparar técnicas cirúrgicas e efeitos do n-butil 2-cianoacrilato e da membrana amniótica bovina na reparação de lesões perfuradas em córneas. Sessenta coelhos da raça Nova Zelândia Branca foram submetidos à ceratoplastia penetrante sob anestesia geral. O grupo 1 (G1) foi tratado com n-butil 2-cianoacrilato; o grupo $2(G 2)$ recebeu um fragmento de membrana amniótica pela câmara anterior e aplicação de n-butil 2-cianoacrilato sobre a lesão; o grupo 3 (G3) foi tratado com a mesma técnica aplicada ao G2, adicionando-se uma bandagem de membrana amniótica cobrindo a córnea e suturada à região do limbo; e o grupo 4 (G4) foi tratado com membrana amniótica suturada nas bordas da lesão e bandagem de membrana amniótica suturada na região do limbo. Foram realizados exames clínico, histológico e histomorfométrico. A membrana atuou como barreira contra o extravasamento do humor aquoso nos grupos 2 e 3, manteve a superfície seca para posterior aplicação do adesivo e impediu o contato do adesivo com as estruturas intraoculares. Os grupos tratados com o adesivo associado à membrana amniótica demonstraram melhores resultados do que aqueles tratados com cada material isoladamente. Assim, a combinação da membrana com o adesivo é indicada neste tipo de lesão.

Palavras-chave: coelhos, córnea, cianoacrilato, glicerina, cirurgia oftálmica

Recebido em 16 de maio de 2012

Aceito em 18 de novembro de 2013

E-mail: kellycpontes@yahoo.com.br 


\section{INTRODUCTION}

The indications for using synthetic adhesives in ophthalmology include small corneal penetrating lesions, descemetoceles, deep stromal ulcers and indolent ulcers (Kern, 1990; Zagelbaum et al., 1999). However, cyanoacrylate derivatives are degraded into toxic products and might cause an inflammatory reaction, corneal vascularization, foreign body reaction and tissue necrosis (Refojo et al., 1971).

Various types of biological membranes have been studied and used in reconstructive ophthalmic surgery. Among them, amniotic membranes have shown excellent results (Kim et al., 2009).

In addition to being antiadhesive, bacteriostatic and lacking antigenicity, the epithelium of the amniotic membrane has specialized functions such as lesion prevention, pain reduction and promotion of epithelialization (Azuara-Blanco et al., 1999).

The present work is based on previous research involving the use of n-butyl 2-cyanoacrylate versus amniotic membrane in penetrating ulcers in the cornea. As Azuara-Blanco et al. (1999) described, the adhesive allows the repair of corneal perforations, although it might cause an inflammatory reaction. The amniotic membrane in a single layer is not effective for this type of lesion (Azuara-Blanco et al., 1999), but it has anti-inflammatory effects and helps re-epithelialization. According to these observations, the combination of an amniotic membrane with n-butyl 2-cyanoacrylate might act synergistically in the repair of perforated lesions in the cornea.

The objectives of this study were to compare surgical techniques and the effects of using nbutyl 2-cyanoacrylate and bovine amniotic membrane to repair perforated lesions in corneas. Thus, experimental perforated lesions in the corneas of rabbits were repaired by means of (i) n-butyl 2-cyanoacrylate, (ii) bovine amniotic membrane preserved in $99 \%$ glycerin at room temperature and (iii) their combination, and the effects of each treatment were compared on the basis of clinical parameters, conventional histology and morphometry.

\section{MATERIAL AND METHODS}

The project was submitted and approved by the Ethics Committee of the Veterinary Department at the Federal University of Viçosa (UFV) under protocol number 30/2008. The bioethical criteria established by the Association for Research in Vision and Ophthalmology (ARVO) National Institutes of Health Publications No 85-23: Revised 1985 were followed according to the Nüremberg code (Goldim, 1995).

The amniotic membrane was prepared according to the literature (Kim and Tseng, 1995), harvested aseptically from a healthy pregnant female bovine with a fetus to term and sent to the Veterinary Hospital of UFV for an elective caesarean operation. The amniotic membrane was immersed in an individual flask containing 99\% glycerin (Glycerin, P.A., Isofar Industry and Trade in Chemicals Ltda., Brazil), stored at room temperature for a minimum of 30 days and evaluated using microbiological analysis to check for bacterial or fungal contamination before use (Pontes et al., 2008).

The following animals were used: 60 healthy New Zealand White adult female rabbits weighing from 2.5 to $3.5 \mathrm{~kg}$. The animals were randomly distributed into 4 groups (15 rabbits each) and kept in individual cages in the bioterium of the Veterinary Department at UFV where they received water, hay and specific rabbit feed.

Preoperatively, all eyes were evaluated by slit lamp biomicroscopy (SL-15 Portable Slit Lamp®, Kowa, Tokyo, Japan), the Schirmer tear test 1 (Ophthalmos Pharmaceutical Industry Ltda., Brazil) and the fluorescein dye test (Ophthalmos Pharmaceutical Industry Ltda., Brazil). Intraocular pressure was measured using an applanation tonometer (TonoPen-XL®, Medtronic Solan, Jacksonville, FL). After the pre-anesthetic evaluation, the animals received general anesthesia and the surgeries were performed under a surgical microscope (DF Vasconcelos, MCT model, line: MC-M222, Brazil).

After operatory region preparations in the right eye of each animal, a penetrating keratoplasty of $2.0 \mathrm{~mm}$ in diameter was performed in the central region of the cornea using a $2.0 \mathrm{~mm}$ disposable 
biopsy punch (Punch for biopsy®, Kolplast, Brazil).

In G1 animals the cornea was dried with an ophthalmic sponge (Merocel Eye Spears®, Medtronic Solan, Jacksonville, FL) for the later application of n-butyl 2-cyanoacrylate
(Histoacryl®, B/Braun, Melsungen, Germany) over the lesion (Figure 1). The application of the adhesive was carefully performed using a $1 \mathrm{~mL}$ syringe and $26 \mathrm{G}$ needle and the minimum amount necessary to fill the lesion in its length and depth.

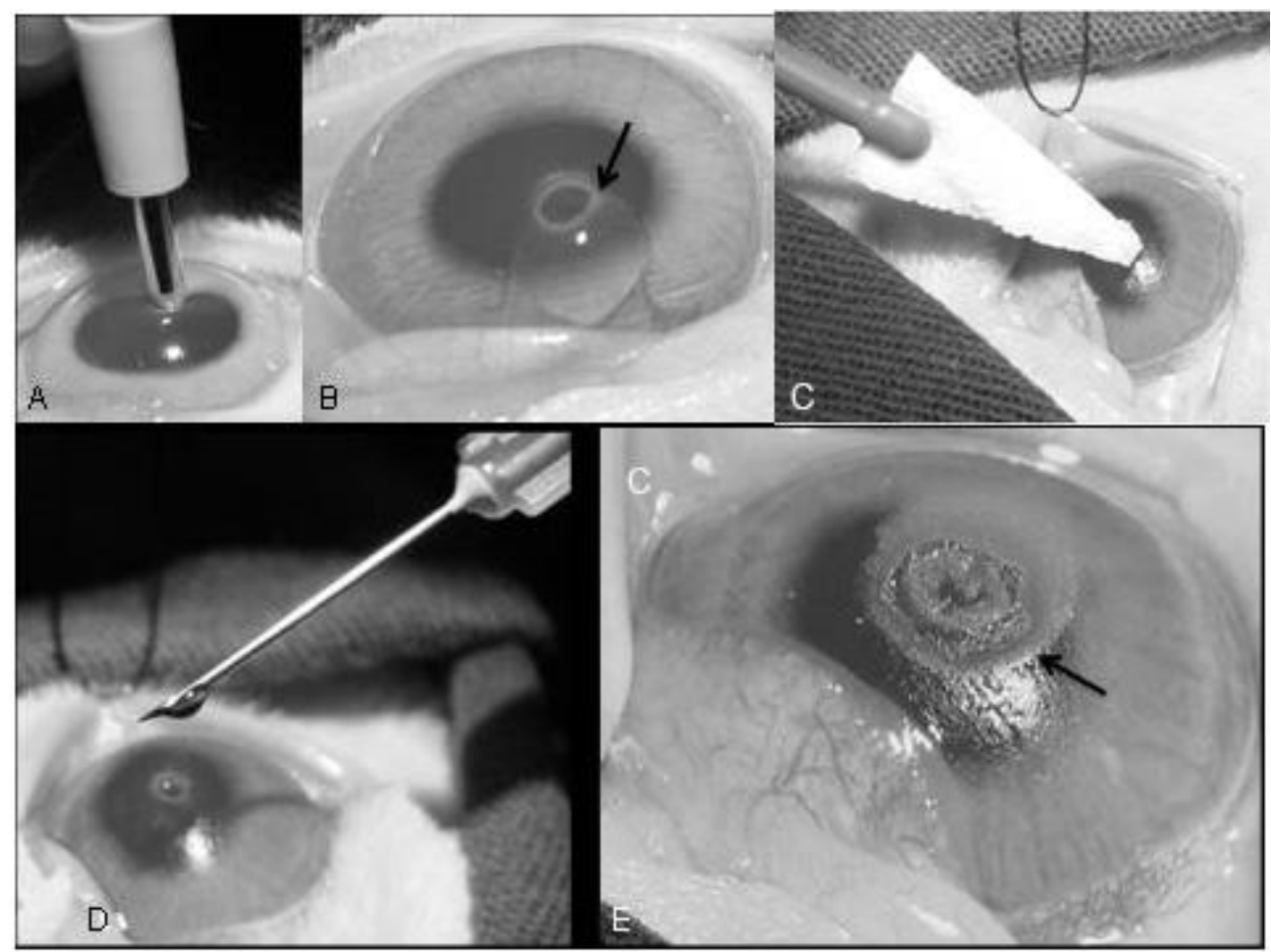

Figure 1. Rabbit. Photographs illustrating the surgical procedure carried out in the corneas in G1. A Penetrating keratectomy with a disposable punch; B - Leakage of the aqueous humor (arrow); C - Drying of the cornea with an ophthalmic sponge; D - Application of n-butyl 2-cyanoacrylate; and E - Final view of the procedure. The arrow shows the adhesive over the lesion.

The corneas from G2 animals were subjected to the same penetrating keratectomy technique performed in G1 animals. A fragment of the amniotic membrane was prepped with a $4 \mathrm{~mm}$ diameter disposable biopsy punch. This fragment was hydrated for 10 minutes in sterile saline and placed under the cornea with the epithelial surface facing up, inside the anterior chamber. The membrane was introduced into the anterior chamber through keratectomy with the assistance of a spatula and iris forceps. Next, the cornea and amniotic membrane exposed through the corneal defect were carefully dried with an ophthalmic sponge, and n-butyl 2-cyanoacrylate was applied (Figure 2) as described for G1.

The corneas of G3 animals were subjected to the same procedure described for G2 animals, but with the addition of a bandage with bovine amniotic membrane previously preserved in $99 \%$ glycerin at room temperature. The membrane was hydrated in sterile saline for 10 minutes, cut into pieces compatible with the cornea and fixed to the limbus in a simple interrupted pattern using 9-0 monofilament nylon thread (Micro Nylon®, Microsuture, São Paulo, Brazil) (Figure 3). 


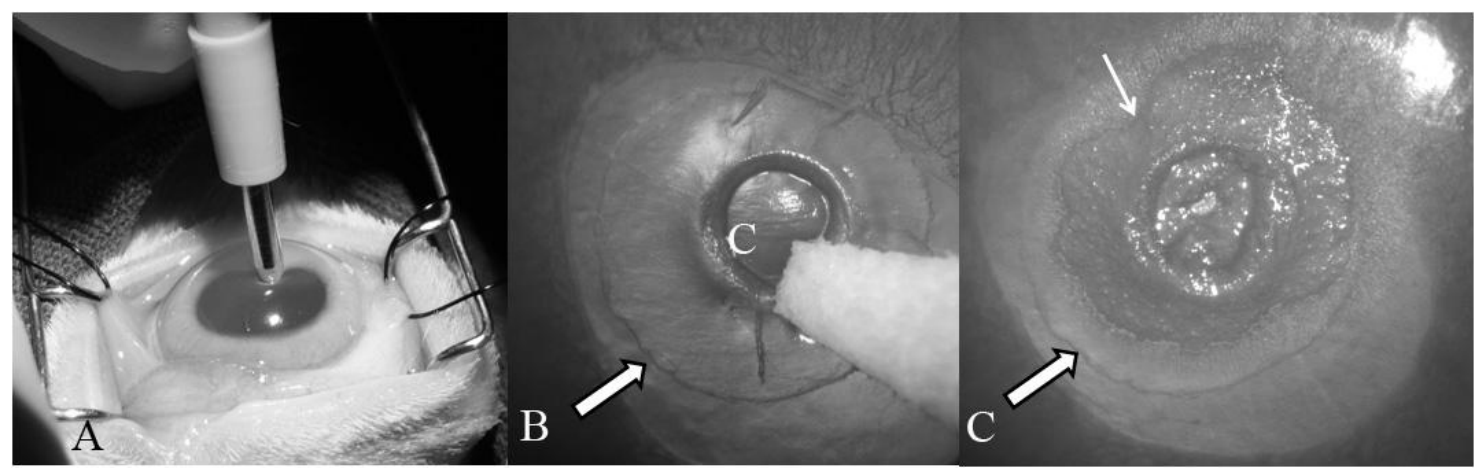

Figure 2. Rabbit. Photographs illustrating the surgical procedure performed in the corneas in G2. A Penetrating keratectomy with a disposable punch; B - Drying of the cornea with an ophthalmic sponge, view of the membrane under the lesion and exposure through it (arrow); and $\mathrm{C}-$ Final view of the procedure. Thin arrow: n-butyl 2-cyanoacrylate over the lesion. Thick arrow: membrane in the anterior chamber.

Keratectomy was carried out in the corneas of G4 animals as described for the other groups. A fragment of amniotic membrane previously hydrated for 10 minutes was cut into a size compatible with the lesion, positioned over the corneal defect with the epithelial surface turned anteriorly and sutured with separate simple stitches at the edges of the lesions using 9-0 monofilament nylon thread. The cornea was dried with an ophthalmic sponge to check for possible leaks. The bandage with the membrane was then applied as described for G3 (Figure 4).

Immediately after the surgical procedure the animals received morphine sulfate $(1 \mathrm{mg} / \mathrm{kg} / \mathrm{SC})$
(Dimorf®, Cristália Pharmaceutical Products, Brazil) (Martin and Kirsipuu, 2008) and an Elizabethan collar that was retained until the corneal lesion was epithelialized as established by a negative fluorescein dye test.

Eye drops with neomycin $0.175 \%$, polymyxin B $10.000 \mathrm{UI} / \mathrm{ml}$ and bacitracin 400UI (Ophthalmos Pharmaceutical Industry Ltda., Brazil) were applied post-operatively on the operated eye (1 drop four times a day for 10 days). Morphine sulfate $(1 \mathrm{mg} / \mathrm{kg} \mathrm{SC}$, every 12 hours) was also administered for 2 days.

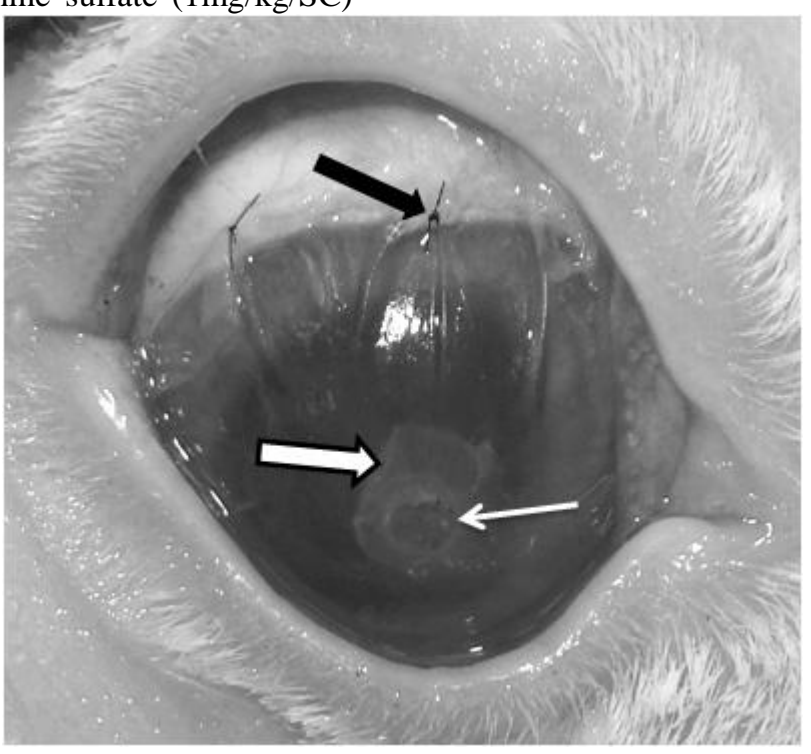

Figure 3. Rabbit. Photograph illustrating the surgical procedure performed in the corneas of G3 rabbits after completion. Thick white arrow: membrane in the anterior chamber; thin white arrow: n-butyl 2cyanoacrylate on top of the lesion; thick black arrow: membrane suture in the region of the limbus. 


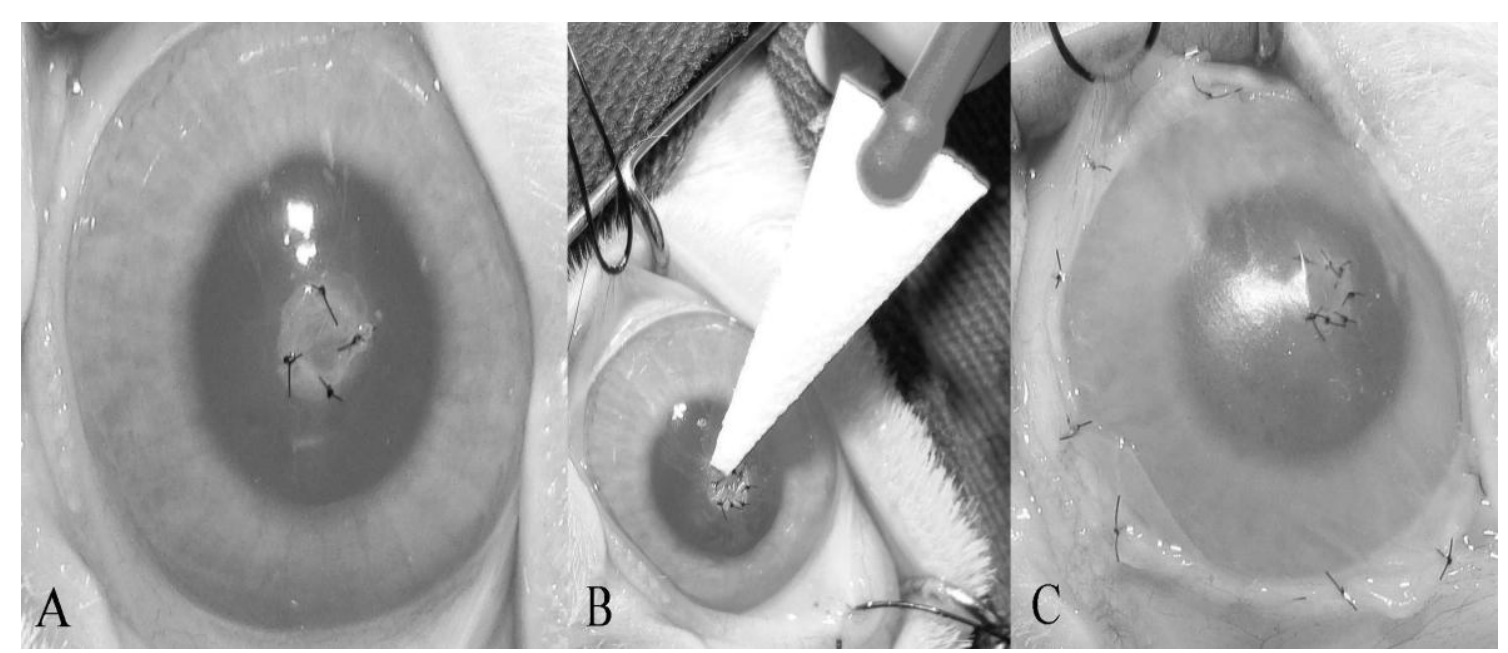

Figure 4. Rabbit. Photographs illustrating the surgical procedure performed in the corneas of G4 rabbits. A - Application of sutures to first fix the membrane in the four cardinal points of the defect; B - Drying of the lesion with an ophthalmologic sponge to check for aqueous humor leakage; $\mathrm{C}-$ Final view of the procedure demonstrating the bandage placed in the region of the limbus.

The elapsed time from the beginning of the surgery (sutures for the immobilization of the eye) to its conclusion was recorded for comparison among the groups.

In the postoperative period the operated eye was assessed daily until the end of the observation period of each animal. Once a day photophobia, blepharospasm, conjunctival hyperemia and chemosis were clinically evaluated, as were parameters related to the cornea (pigmentation, edema and vascularization), anterior chamber (hyphema, hypopyon and fibrin) and lens (opacity). The occurrence of signs related to uveitis, the presence or absence of miosis, swelling and changes in iris color were also evaluated. The fluorescein dye test (classified as positive or negative) was carried out starting 48 hours after the surgery. The test was repeated daily until the result was negative. In the animals in G3 and G4, which received a bandage with amniotic membrane as part of the treatment, the fluorescein dye test was started only after the spontaneous loss of the bandage.

The 15 samples selected for each group were randomly divided again into 5 subgroups consisting of 3 animals each. The corneas were collected for histological and morphometric evaluation according to the following criteria: subgroup 1 (T1): 2 days after surgery; subgroup 2 (T2): 7 days after surgery; subgroup 3 (T3): 15 days after surgery; subgroup 4 (T4): 21 days after surgery and subgroup 5 (T5): 30 days after surgery.

To harvest the corneas the animals were euthanized and the operated eyes were enucleated, and the corneas were prepared for paraffin embedding. $4 \mu \mathrm{m}$ sections were made and stained with hematoxylin \& eosin (H\&E).

Histology and morphometry were conducted under an optical microscope to evaluate the degree of epithelialization of the cornea and the presence of leucocytes, edema and vessels. The epithelialization of the cornea was classified as present or absent, and when present, as complete or incomplete; leucocytes, edema and newly formed vessels were classified as present or absent.

For the morphometry, photomicrographs of the $\mathrm{H} \& \mathrm{E}$ slides were made on a light microscope (Olympus® America Inc. CX 31 - Color Camera for light microscopy SC 20, São Paulo, Brazil). The photomicrographs were evaluated using the Image Pro Plus software system, version 4.5.

The variables were subjected to Normality (Lilliefors) and Homoscedasticity (Cochran) tests. Data that met the normality and homoscedasticity criteria were subjected to analysis of variance (ANOVA) followed by the Tukey test at $5 \%$ probability. Those that did not meet the Normality and Homoscedasticity 
criteria were analyzed using the Kruskal-Wallis test complemented by the Dunn test at $1 \%$ and $5 \%$ probability, respectively. Statistics were evaluated between the groups at first not considering the time-points and then were evaluated between the groups at each time-point. All tests were carried out using the GraphPad InStat software system, Version 3.0.

\section{RESULTS AND DISCUSSION}

Glycerin at $99 \%$ was chosen to for use in this study because it has proven to be an effective medium for preserving bovine amniotic membrane at room temperature (Pontes et al., 2010), it is easy to obtain, easy to handle and is inexpensive (Pontes et al., 2008).

With the exception of groups 1 and 2, the surgery time (calculated in minutes) was statistically different $(\mathrm{p}<0.05)$ between the groups (Table 1) and revealed that the technique applied in G2 was the simplest. In the G1 procedure, apparently the easiest procedure, constant aqueous humor leakage made it difficult to dry the surface for the later application of the adhesive. In groups 2 and 3, the fragment of amniotic membrane positioned within the anterior chamber served as an effective barrier against the outflow of aqueous humor through the perforation in the cornea. The aqueous humor pressed the amniotic membrane directly on the lesion, pushing it against the corneal endothelium and thereby obstructing the perforation and preventing further outflow. The bandages applied in G3 and G4 and also the sutures applied in $\mathrm{G} 4$ for membrane fixation prolonged the surgical time, making it more demanding.

The average presence of photophobia was the same as blepharospasm, and was 13.99 days in $\mathrm{G} 1$ and $\mathrm{G} 2,21.42$ days in G3 and 30 days in G4. No differences were seen $(p>0.01)$ between the groups by the Kruskal-Wallis test.

Table 1. Medians and average in which the parameters were seen after the surgical treatment established for the respective groups of rabbits

\begin{tabular}{lcccc}
\hline Groups & $\mathrm{G} 1(\mathrm{n}=15)$ & $\mathrm{G} 2(\mathrm{n}=15)$ & $\mathrm{G} 3(\mathrm{n}=15)$ & $\mathrm{G} 4(\mathrm{n}=15)$ \\
\hline $\begin{array}{l}\text { Average surgery time (minutes) } \\
\text { Positivity of the fluorescein dye test (median } \\
\text { duration in days) }\end{array}$ & $28.95 \mathrm{c} \pm 9.46$ & $24.00 \mathrm{c} \pm 6.09$ & $42.85 \mathrm{~b} \pm 6.56$ & $73.07 \mathrm{a} \pm 14.91$ \\
$\begin{array}{l}\text { Beginning of epithelialization by } \\
\text { histopathology (days) }\end{array}$ & $30.00 \mathrm{a}$ & $22.85 \mathrm{a}$ & $21.99 \mathrm{a}$ & $30.00 \mathrm{a}$ \\
$\begin{array}{l}\text { Completion of epithelialization by } \\
\text { histopathology (days) }\end{array}$ & 15 & $<15$ & $<15$ & 15 \\
$\begin{array}{l}\text { Accession of the corneal epithelial to the } \\
\text { basement membrane (number of animals) }\end{array}$ & $>30$ & 15 & 15 & 30 \\
$\begin{array}{l}\text { Corneal edema (median of duration on days) } \\
\text { ( }\end{array}$ & $21.42 \mathrm{ab}$ & $12.85 \mathrm{~b}$ & $17.14 \mathrm{~b}$ & $30.00 \mathrm{a}$ \\
$\begin{array}{l}\text { Opacity in the anterior capsule of the lens } \\
\text { (median of days) }\end{array}$ & $30.00 \mathrm{a}$ & $30.00 \mathrm{a}$ & $0.00 \mathrm{ab}$ & $0.00 \mathrm{~b}$ \\
$\begin{array}{l}\text { Number of animals that presented leucocytes in } \\
\text { the lesioned stroma }\end{array}$ & $4 \mathrm{ab}$ & $2 \mathrm{~b}$ & $2 \mathrm{~b}$ & $10 \mathrm{a}$ \\
\hline
\end{tabular}

Note: G1= Group 1; G2= Group 2; G3= Group 3; G4= Group 4; n= Size of sample. (*) Averages with different letters in the same line differ from each other by the Tukey test $(\mathrm{P}<0.05)$. (§) Medians followed by different letters in the same line differ from each other at $5 \%$ probability level by the Dunn test. $\left.{ }^{* *}\right)$ Medians followed by the same letter in the same column do not differ at $1 \%$ probability by the Kruskal-Wallis test.

The amniotic membrane bandage impaired the evaluation of the cornea in G3 and G4, sometimes making it impossible. It prolonged the surgery time, prevented examination of the cornea and anterior chamber and failed to decrease ocular discomfort. Corneal edema could be detected only after the bandage had fallen off, being visible only in the perilesional area and of mild intensity. Differences $(\mathrm{p}<0.05)$ were noted between the groups by the Dunn test (Table 1). 
In this study, the use of amniotic membrane in the anterior chamber prevented the outflow of aqueous humor, enabling the safe and effective application of the surgical adhesive. No sutures were required for fixation in any of the 30 animals that received it.

The average number of days in which chemosis was found was 1.99 days in all groups. In these variables, no differences were seen $(p>0.01)$ between the groups by the Kruskal-Wallis test. This can be attributed to mechanical irritation of the conjunctiva from the surgical manipulation and from the sutures used to immobilize the ocular bulb, as seen in an earlier study (Pontes et $a l ., 2008)$. The average number of days in which conjunctival hyperemia occurred was 18.00 days in G1, 21.42 days in G2 and G3 and 30.00 days in G4. The presence of conjunctival hyperemia, which lasted longer than the chemosis, can be attributed to the irregularity of the surface of the adhesive and to the sutures applied (in the corneas that received them).

The clinical and histopathological examinations conducted at the predetermined time points revealed no vascularization or pigmentation in the operated corneas from any of the groups. This suggests that n-butyl 2-cyanoacrylate does not induce vascularization. These results are in agreement with those of Ollivier et al. (2001), who applied the same adhesive on the corneal surface. In contrast, Aronson et al. (1970) found corneal vascularization when they applied octylcyanoacrylate. It is clear that the toxicity of an adhesive is lower when it has a longer chain (Refojo et al., 1971); however, it would not be prudent to state that octyl-cyanoacrylate is more toxic than n-butyl 2-cyanoacrylate based only on these results and without a direct comparison. The absence of vessels in the cornea was not due to the antiangiogenic action of the amniotic membrane, because G1 did not receive amniotic membrane and presented no vessel formation. The absence of vascularization explains the absence of corneal pigmentation because, according to Kern (1990), vascularization precedes pigment deposition.

The fluorescein dye test was performed in G3 and G4 only at 7 after days of surgery, when the bandage had fallen off spontaneously. Before this time the test was prevented by the presence of the bandage. There were no differences
( $>0.01)$ between the treatments by the KruskalWallis test (Table 1).

In all groups corneal epithelialization was not histologically assessed until 15 days after the procedure. At this time, epithelialization proved to be complete in three G3 animals and two G2 animals. On the $21^{\text {st }}$ day of observation, epithelialization was still incomplete in one G1 animal and one G4 animal. At this time-point, all animals in G2 and G3 presented complete epithelialization. On the $30^{\text {th }}$ day after surgery, one G1 animal presented incomplete epithelialization, whereas epithelialization was complete in all animals in the other groups (Table 1).

According to Kato et al. (2000), the normalization of the basement membrane is essential for maintaining adhesion of the epithelium to the stroma. The authors state that the collagen fibers of the basement membrane require more than a month to recover their normal condition after the completion of penetrating keratoplasty in rabbits; therefore, repairing lesions that affect the basement membrane is also time-consuming.

On the fifteenth day after surgery the epithelium was hyperplastic with hypertrophic epithelial cells in two animals from group 2 and two animals from group 3. At 21 days the epithelium was hyperplastic in all animals. At 30 days the epithelium was hyperplastic in two animals from G1 and G2 and in all animals from G4 and G3. Epithelial hyperplasia is a phenomenon that is observed when the epithelium is re-organizing itself and indicated that G2 and G3 were in a more advanced state of repair. Epithelial hyperplasia reflects the attempt to restore the original shape of the cornea and to re-establish the regularity of its surface (Neto et al., 2005).

Corneal edema has an important influence on the integrity of both the corneal epithelium and endothelium. The absence of one of these cell layers allows water to go through the stroma, resulting in corneal edema (Slatter and Dietrich, 2007). In this study, corneal edema monitoring suggested that repair of the epithelium and endothelium occurred more efficiently in the animals in groups 2 and 3 . The basement membrane of the cornea showed signs of satisfactory repair due to its adherence to corneal 
stroma in 3 animals from G1, 5 animals from G2 and G3, and 1 animal from G4. The KruskalWallis test revealed no difference $(p>0.05)$ between the groups regarding the repair of the basement membrane of the cornea.

We believe that the superior repair found in groups 2 and 3 was due to the amniotic membrane acting as a scaffold for cell migration, which was observed histologically by the migration of endothelial cells on the amniotic membrane, and due to its presence for up to 30 days in more animals in groups 2 and 3 than in the other groups. This role of the membrane favors corneal repair, as seen in previous studies (Wilcock, 2008).

In the post-op period, although inflammatory cells were noticed in the injured and perilesional stroma of the corneas in all groups, a statistical difference $(p<0.05)$ was noted between the groups by the Dunn test (Tab. 1). The adhesive also acted as a physical barrier, a waterproof membrane against the ingrowth of leukocytes from the lacrimal film to the stroma. Moreover, better results were obtained when the membrane was used because it decreases inflammation without eliminating it. Leukocytes are a part of the repair process, and most agree that they should not be eliminated from this process, being important for both the elimination of cell debris from apoptosed keratinocytes and the production of many cytokines involved in the immune response (Wilcock, 2008).

Signs related to the occurrence of uveitis such as hypopyon, hyphema, fibrin deposition in the anterior chamber, miosis, swelling of the iris and iris color changes were not observed, and they were therefore classified as absent in all the animals in the different groups analyzed.

The presence or absence of synechia was evaluated, and it did not differ between the groups $(p>0.01)$ by the Kruskal-Wallis test. There was anterior synechia in two animals in G1. One occurred at the 1 o'clock position, and it was dissolved by the $4^{\text {th }}$ day after surgery. The other was visible at the 9 o'clock position, and it persisted throughout the observation period.

Opacity was observed in the anterior capsule of the lens in 11 animals in G1, in 7 animals in G2 and in 6 animals in G3. There was a statistical difference $(p<0.05)$ between the groups $($ Tab. 1) by the Dunn test.

Due to the deformation of the bulb from the keratectomy and because the intraocular structures were not protected, the adhesive reached intraocular structures during its application on the lesion in G1. Although a cap of fibrin that formed from the aqueous humor protected the intraocular structures, it was not completely efficient and allowed accidental contact of a small amount of adhesive with the anterior capsule of the lens or with a small central portion of the iris. Such an event may explain the opacity of the anterior capsule of lens and the formation of anterior synechiae, since no signs of uveitis were noticed in these animals. The accidental introduction of adhesive into the anterior chamber is associated (among other complications) with the formation of anterior and posterior synechiae (Markowitz et al., 1995).

Searching for an alternative to the use of viscoelastic, the amniotic membrane was placed in the internal surface of the corneal lesion. In addition to promoting epithelialization, it also prevented the adhesive from contacting intraocular structures. This was because the amniotic membrane blocked the perforation in the cornea, thus preventing the adhesive from entering the anterior chamber. The application of viscoelastic in the anterior chamber to prevent such complications is indicated for perforations with a diameter greater than $1 \mathrm{~mm}$ (Hirst and De Juan, 1982). Its removal is recommended to prevent glaucoma (Wilkie and Gemensky, 2004), but the manipulation inside the anterior chamber necessary to remove the viscoelastic is responsible for the loss of endothelial cells (Rafuse and Nichols, 1992).

The opacity observed in the anterior capsule of the lens in G1 was believed to have been due to contact by the adhesive, which penetrated into the anterior chamber during its application. In G2 and G3, the maneuvers performed to position the membrane correctly inside the anterior chamber might have injured the capsule of the lens. The resulting opacity, although affecting only a very small point, was considered for statistical analyses, and it disappeared in some of the animals during the observation period. It was observed that the amniotic membrane prevented the adhesive from contacting intraocular 
structures. When this happened in G1, the opacity of the lenticular capsule proved to be more affected than in G2 or G3. In G4 no adhesive was used, nor was there any type of manipulation inside the anterior chamber, explaining the absence of opacity. The opacity of the lens was present for a shorter time in G3 than in $\mathrm{G} 2$, which is why a statistical difference was found between $\mathrm{G} 2$ and G4 but not between G3 and G4.

\section{CONCLUSIONS}

The results obtained from this study reveal that the surgical techniques used in G2 and G3, using an amniotic membrane with n-butyl 2cyanoacrylate, were easier to execute and more efficient for the repair of $2 \mathrm{~mm}$ corneal perforations when compared to techniques using only adhesive or only amniotic membrane sutured to the lesion. The technique used in group 2 was the best because it was easier to carry out and provided results similar to those of G3 with regard to the repair of the injury. Thus, the combination of amniotic membrane with adhesive is indicated for this type of lesion.

\section{ACKNOWLEDGEMENTS}

To FAPEMIG, CAPES and Ophthalmos Pharmaceutical Industry, Ltda for their support.

\section{REFERENCES}

ARONSON, S.B.; MCMASTER, P.R.B.; MOORE, T.E. et al. Toxicity of the cyanoacrylates. Arch. Ophthalmol., v.84, p.342-349, 1970.

AZUARA-BLANCO, A.; PILLAI, C.T.; DUA, H.S. Amniotic membrane transplantation for ocular surface reconstruction. Braz. J. Ophthalmol., v.83, p.399-402, 1999.

GOLDIM, J.R. (Ed). Pesquisa em saúde e direitos dos animais. Porto Alegre: HCPA, 1995. 28p.

HIRST, L.W.; DE JUAN, E.J. Sodium hyaluronate and tissue adhesive in treating corneal perforations. Ophthalmol., v.89, p.12501253, 1982.
KATO, T.; NAKAYASU, K.; KANAI, A. Corneal wound healing: immunohistological features of extracellular matrix following penetrating keratoplasty in rabbits. Japan. J. Ophthalmol., v.44, p.334-341, 2000.

KERN, T.J. Ulcerative keratitis. Vet. Clin. N. Am. Small Anim. Pract., v.20, p.643-666, 1990.

KIM, J.Y.; CHOI, Y.M.; JEONG, S.W. et al. Effect of bovine freeze-dried amniotic membrane (Amnisite-BA ${ }^{\mathrm{TM}}$ ) on uncomplicated canine corneal erosion. Vet. Ophthalmol. v.12, p.36-42, 2009.

KIM, J.C.; TSENG, S.C.G. Transplantation of preserved human amniotic membrane for surface reconstruction in severely damaged rabbit corneas. Cornea., v.14, p.473-484, 1995.

MARKOWITZ, G.D.; ORLIN, S.E.; FRAYER, W.C. et al. Corneal endothelial polymerization of histoacryl adhesive: a report of a new intraocular complication. Ophthalm. Surg., v.26, p.256-258, 1995.

MARTIN, M.; KIRSIPUU, V. Rabbit anesthesia. Cornell Center for Animal Resources and Education. Standard Operating Procedures. CARE:103.01, 2006. Available in http://www.research.cornell.edu/CARE/documen ts/SOPs/CARE103.pdf. Accessed October 20, 2008.

NETO, M.V.; AMBRÓSIO Jr, R.; CHALITA, M.R. et al. Resposta cicatricial corneana em diferentes modalidades de cirurgia refrativa. Arq. Bras. Oftalmol. v.68, p.140-149, 2005.

OLLIVIER, F.; DELVENDIER, M.; REGNIER, A. Tolerance of the rabbit cornea to an n-butylester cyanoacrylate adhesive (Vetbond®). Vet. Ophthalmol., v.4, p.261-266, 2001.

PONTES, K.C.S.; BORGES, A.P.B.; DUARTE, T.S. et al. Membrana amniótica canina utilizada como bandagem em úlcera superficial de córnea de coelhos - Aspectos clínicos. Arq. Bras. Med. Vet. Zootec., v.60, p.1069-1074, 2008.

PONTES, K.C.S.; DUARTE, T.S.; MACHADO, D.P.D. et al. Membrana amniótica bovina, preservada em glicerina, no tratamento de úlcera de córnea em um cão e de sequestro corneal em dois felinos - Relato de casos. Rev. Clin. Vet., v.85, p.88-96, 2010. 
RAFUSE, P.E.; NICHOLS, B.D. Effects of Heaton vs Viscoat on endothelial cell count and morphology after phaceomulsification and posterior chamber lens implantation. Can. J. Ophthalmol., v.27, p.125-129, 1992.

REFOJO, M.F.; DOHLMAN, C.H.; KOLIOPOULOS, J. Adhesives in ophthalmology: a review. Surv. Ophthalmol., v.15, p.217-236, 1971.

SLATTER, D.; DIETRICH, U. Córnea e esclera. In: SLATTER, D. (Ed) Manual de cirurgia de pequenos animais. São Paulo: Manole, 2007. p.1368-1396.
WILCOCK, B. General pathology of the eye. In: SLATTER, D. (Ed) Slatter's Fundamentals of Veterinary Ophthalmology 4.ed. Philadelphia: Saunders Elsevier, 2008. p.62-80.

WILKIE, D.A.; GEMENSKY-METZLER, A.J. Agents for intraocular surgery. Vet. Clin. S. An. Pract., v.34, p.801-823, 2004.

ZAGELBAUM, B.M.; SCHWARTZ, B.H.; NELSON, D.B. Accidental instillation of $\mathrm{N}$ butyl cyanoacrylate into the anterior chamber. Braz. J. Ophthalmol., v.83, p.878-884, 1999. 